\title{
Neutral detergent fibre in piglet diets: performance and gastrointestinal implications
}

\author{
Fibra em detergente neutro na ração de leitões: desempenho e \\ implicações gastrointestinais
}

\author{
Rafael Carlos Nepomuceno ${ }^{1 *}$, Pedro Henrique Watanabe1, Ednardo Rodrigues Freitas', \\ Luiz Euquerio de Carvalho'1, Emanuela Lima de Oliveira', Alini Mari Veira ${ }^{2}$
}

\author{
'Universidade Federal do Ceará/UFC, Departamento de Zootecnia, Fortaleza, CE, Brasil \\ Universidade Estadual de São Paulo/UNESP, Faculdade de Ciências Agrárias e Veterinárias/FCAV, Jaboticabal, SP, Brasil \\ ${ }^{*}$ Corresponding author: rafael@zootecnista.com.br \\ Received in november 18, 2015 and approved in february 11, 2016
}

\begin{abstract}
The intestinal health of piglets depends on the balance between diet, microflora and mucosal integrity. Disruption of this balance can compromise the digestive functions, leading to diarrhoeal frame and decline in performance of piglets. However, the level and type of fibre can limit digestive disorders. Thirty newly weaned piglets were used to evaluate the levels of neutral detergent fibre (NDF) in diets regarding performance, $\mathrm{pH}$, viscosity and concentration of short chain fatty acids of digestive contents, gastrointestinal transit time, morphology of the intestinal mucosa, weights of organs and occurrence of diarrhoea. NDF level had quadratic effect on weight gain and feed conversion ratio of piglets, estimating best results at the level of $10.4 \%$. NDF level had no effect on the $\mathrm{pH}$, viscosity and concentration of short chain fatty acids. NDF levels below $10.2 \%$ or above $13.5 \%$ reduced the transit time of digesta. There was quadratic effect on villus height in the duodenum and jejunum and in the crypt depth of jejunum. There was linear increase in stomach, caecum and colon weights and linear decrease in the occurrence of diarrhoea according to increasing NDF levels. It is concluded that levels below $10.2 \%$ and above $13.5 \%$ reduce the transit time of digesta, whereas $12.2 \%$ NDF level results in better mucosa structure of the small intestinal, with an increase in the weights of the stomach, caecum and colon and a reduction in the occurrence of diarrhoea with increasing NDF level in diets, resulting in better performance of weaned piglets with $10.4 \%$ of NDF.
\end{abstract}

Index terms: Short chain fatty acids; pigs; transit time; viscosity.

\section{RESUMO}

A saúde intestinal em leitões depende do equilíbrio entre dieta, microflora e integridade da mucosa. Perturbações desse equilíbrio podem comprometer as funções digestivas, conduzindo a quadro diarreico e queda no desempenho dos leitões. Nesse sentido, o nível e tipo de fibra podem limitar as perturbações digestivas. Utilizou-se 30 leitões recém desmamados objetivando avaliar níveis de fibra em detergente neutro (FDN) nas dietas sobre o desempenho, pH, viscosidade concentração de ácidos graxos de cadeia curta dos conteúdos digestivos, tempo de trânsito gastrointestinal, do ceco, morfologia da mucosa intestinal, pesos dos órgãos e ocorrência de diarreia. Observou-se efeito quadrático do nível de FDN sobre o ganho de peso e conversão alimentar dos leitões, estimando-se melhores resultados no nível de $10,4 \%$. Não houve efeito do nível de FDN sobre o pH, viscosidade e concentração de ácidos graxos de cadeia curta da digesta. Níveis de FDN abaixo 10.2 ou acima de 13,5\% reduziu o tempo de trânsito da digesta. Houve efeito quadrático sobre a altura das vilosidades do duodeno e jejuno e na profundidade das criptas do jejuno. Houve aumento linear no peso do estômago e do ceco e cólon e redução linear na ocorrência de diarreia conforme houve aumento dos níveis de FDN. Concluiu-se que níveis abaixo de 10,2 e acima de 13,5\% reduzem o tempo de trânsito da digesta, enquanto que o nível de 12,2\% de NDF resulta na melhor estrutura da mucosa do intestino delgado, havendo aumento nos pesos de estômago, ceco e cólon e redução da ocorrência de diarréia com o aumento do nível de FDN, resultando um melhor desempenho de leitões desmamados com 10,4\% de FDN.

Termos para indexação: Ácidos graxos de cadeia curta; suínos; tempo de trânsito; viscosidade.

\section{INTRODUCTION}

The maintenance of the gut health of piglets depends on a balance among dietary nutrients, commensal microflora and mucosal integrity. Any disturbance of this balance can change the physicochemical properties of digesta and digestive functions, unleashing a diarrhoeal condition with negative impacts on growth and animal mortality rate.

With regard to diet in the nursery phase, modulation of the level and type of dietary fibre (DF) represents a way of maintaining digestive functions because they 
alter alimentary bolus properties, affecting the microbiota composition and its metabolic activity, limiting digestive disorders and preserving the health of piglets (Bach Knudsen, 2001; Montagne; Pluske; Hampson, 2003).

Among the physiological and metabolic effects of DF on the nutrition and intestinal health of piglets, changes in $\mathrm{pH}$, viscosity, water-holding capacity and the amount of alimentary bolus stand out (Annison; Choct, 1994), along with the populations and activities of intestinal microorganisms, as well as their interaction with the intestinal mucosa, and the effects on cell division and endogenous excretion rate (Refstie et al., 1999; Bach Knudsen, 2001; Wenk, 2001). In this perspective, although studies have been conducted to evaluate sources of fibrous feeds, researches related to DF level, specifically for piglets, are scarce.

With regard to the methods used to determine fibre constituents, those based on enzymatic digestion are the ones that will best express the DF content of feeds; however, they are still unusual, expensive and difficult to implement, and require a large number of replicates. On the other hand, the method proposed by Van Soest and Wine (1967) for determining the neutral detergent fibre (NDF) is widely used in animal nutrition, because it is a fast analytical procedure and simple application, and, as it has hemicellulose among its constituents, it is configured as the data with the best correlation with total DF, in addition to appearing in most of the chemical composition of feed system databases for animals (National Research Council-NRC, 2012; Rostagno et al., 2011).

Based on the above, the objective of this research was to evaluate the effects of NDF levels on the diets of weanling piglets in relation to the performance, $\mathrm{pH}$ and viscosity of digestive content, gastrointestinal transit time, the concentration of short chain fatty acids in caecum content, the morphology of intestinal mucosa, the weight of digestive organs and the occurrence of diarrhoea.

\section{MATERIALS AND METHODS}

The experimental protocols were approved by the Animal Research Ethics Committee of the Universidade Federal do Ceará, under protocol $55 / 2013$ of 27 November 2013, and in accordance with the Ethical Principles in Animal Experimentation adopted by the Brazilian College of Animal Experimentation.

\section{Pig husbandry, experimental design and diets}

The experiment lasted 21 days and was carried out in the Setor de Suinocultura of the Departamento de Zootecnia of the Universidade Federal do Ceará with 30 castrated male piglets (Topigs genetic line), weaned at 21 days of age, with an average weight of $7.48 \pm 0.46 \mathrm{~kg}$.

The piglets were distributed in a randomized block design with five treatments, considering neutral detergent fibre (NDF) levels of 8.5, 10.5, 12.5, 14.5 and $16.5 \%$, with six replicates per treatment and one animal per plot, and with the initial weights of the animals being the criteria for the formation of blocks.

The animals were housed in pens with a semiautomatic feeder, nipple drinker and side curtains, which were handled daily. Climate monitoring was carried out through four dataloggers distributed within the shed 60 $\mathrm{cm}$ above the ground. Temperature and relative humidity were recorded about every 10 minutes.

Feedstuff was analysed for dry matter (DM) and crude protein (CP) according to Association Of Official Analytical-AOAC (1990), and NDF and acid detergent fibre (ADF) according to the methodology described by Van Soest, Robertson and Lewis (1991). From the analysis, the values obtained were $89.71 \% \mathrm{DM}, 8.21 \%$ CP, $12.47 \%$ NDF and $2.30 \%$ FDA for corn; $90.60 \%$ DM, $38.96 \%$ CP, $18.54 \%$ NDF and 10.01\% FDA for soybean meal; $89.96 \%$ DM, $32.96 \%$ CP, $15.15 \%$ NDF and $7.28 \%$ FDA for extruded soybean; and $94.40 \% \mathrm{DM}, 14.79 \% \mathrm{CP}$, $38.10 \% \mathrm{NDF}$ and $28.18 \%$ FDA for wheat bran. According to similarities in the mean values for the ingredients advocated by Rostagno et al. (2011), we used the values of the metabolizable energy, fat, calcium, phosphorus, sodium, lysine, methionine, threonine, tryptophan and starch of the ingredients according to the same authors.

The experimental diets used (Table 1) were isocaloric and isonutritive, taking into consideration the nutritional requirements of pigs from 21 to 32 and 33 to 42 days of age, according to Rostagno et al. (2011). Wheat bran was the main source of fibre used to promote increased NDF level in the diets. During the whole experimental period, the feed and water were supplied ad libitum.

\section{Measurements and laboratory analysis}

The occurrence of diarrhoea was evaluated once a day, by the same observer, at 3:00 p.m. Through visual analysis, the stools were classified according to their physical characteristics, with soft and watery stools being considered as diarrhoea. 


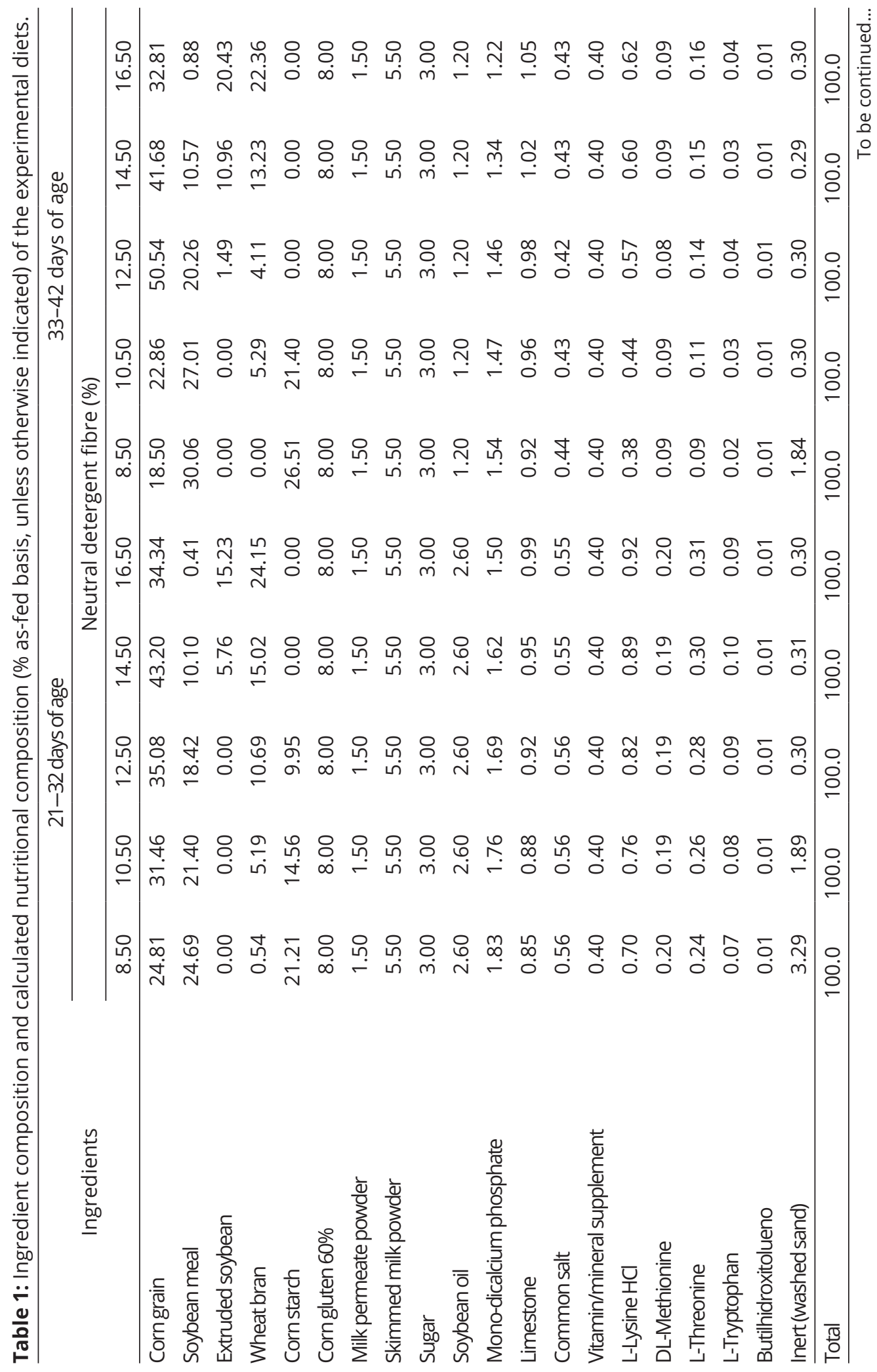




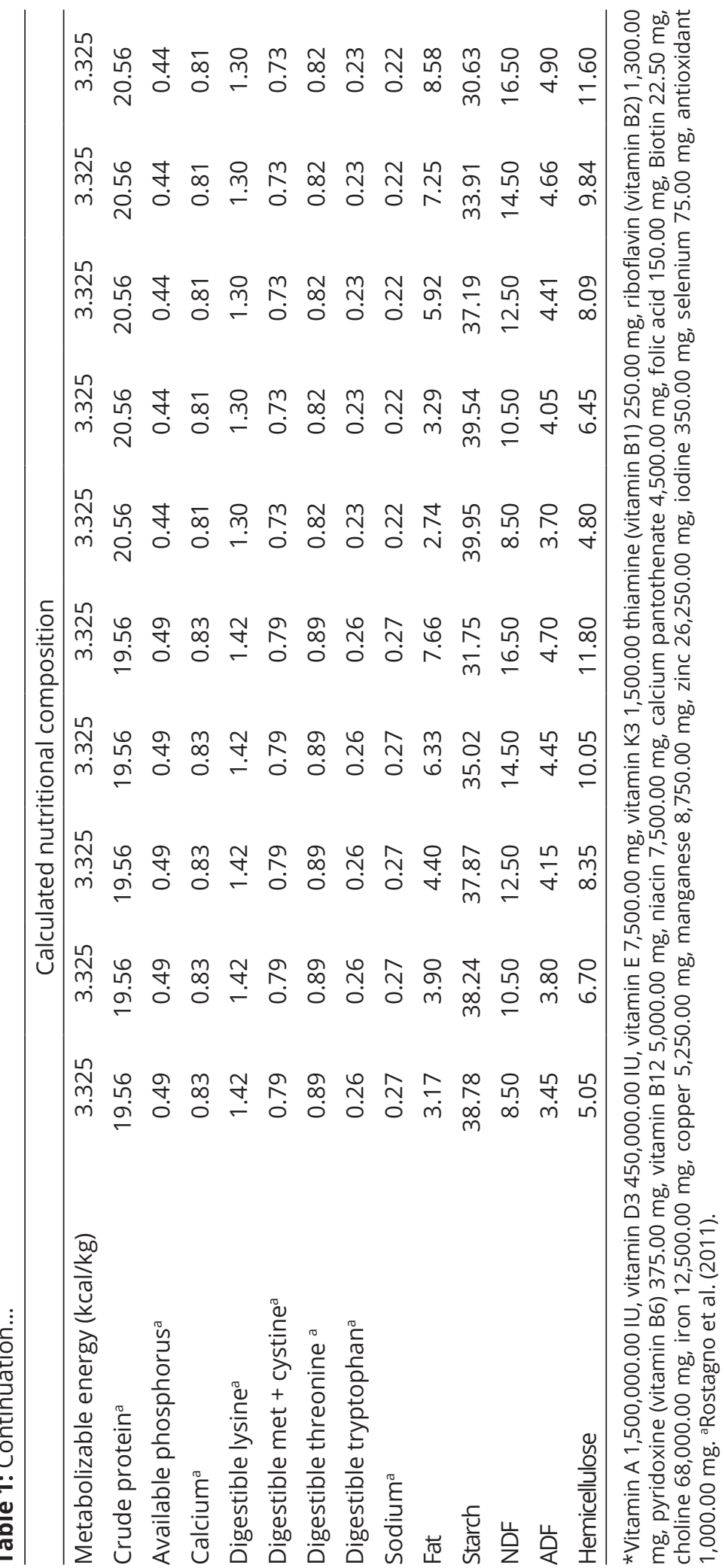


The gastrointestinal transit time of digesta was evaluated by the method described by Zhang et al. (2001). Thus, at 32 days of age the respective experimental diets were offered to the piglets, marked with $0.5 \%$ Celite 545 , and the amounts were calculated based on the consumption and metabolic weight of the animal. After the period of consumption, ration remains were collected and feeders fuelled with unmarked experimental rations. After 15 hours the supply of rations marked, the faeces were collected at intervals of 3 hours for a period of 12 hours, with the samples being stored frozen. Subsequently, the stools were defrosted, subjected to pre-drying in an oven with forced air circulation at $55^{\circ} \mathrm{C}$ for 72 hours, ground in a porcelain mill, digested in $4 \mathrm{~N}$ hydrochloric acid and burned in a muffle furnace in accordance with the methodology of Van Keulen and Young (1977). From these data the acid insoluble ash (AIA) concentrations excreted by the piglets at the different times of collections were determined.

The animals and their respective feed were weighed at the beginning and end of each phase, as well as feed leftovers, which were collected in plastic bags and quantified daily for correction of feed intake. Based on the weights of the animals and feed intake, the average daily feed intake (ADFI), average daily gain (ADG) and feed conversion ratio (FCR) were determined.

At the end of the experimental period, all the animals were weighed individually, stunned by electronarcosis and slaughtered. There was no solids fasting prior to slaughter. Immediately after slaughter, the viscera were exposed by a midline incision and the sections of the gastrointestinal tract were insulated with double ligature.

Samples were removed from the stomach, small intestine and caecum contents for measuring the $\mathrm{pH}$ using a digital $\mathrm{pH}$ meter, model $\mathrm{HI} 2221$, in a standard temperature of $25{ }^{\circ} \mathrm{C}$ and with $95 \%$ sensitivity. The same samples were diluted in distilled water in the ratio $1: 1$ and centrifuged at $12,000 \mathrm{rpm} \times \mathrm{g}$ for 8 minutes, and the supernatant was used to determine the viscosity in a shear rheometer, model DSR 5, with a shear rate of $60 \mathrm{~s}^{1}$.

Concentrations of short chain fatty acids in the caecal contents were analysed according to the methodology described by Erwin, Marco and Mery (1961). For this, caecum content samples of approximately $10 \mathrm{~g}$ were weighed and acidified with $30 \mathrm{ml}$ of formic acid to inactivate fermentation processes, and were kept under refrigeration for 72 hours and homogenized twice daily. After this period, the samples were centrifuged at 5000 rpm at $15{ }^{\circ} \mathrm{C}$ for 15 minutes to separate the supernatant, which was frozen and later analysed. The analyses were performed by gas chromatography, using a gas chromatograph (Model Focus GC, ThermoScientific, with an AS 3000 autosampler), equipped with a glass column 2 metres long x $1 / 8$ " in diameter, packed with 80/120 Carbopack B-DA/4\% Carbowax 20M calibrated with injections of $1 \mu \mathrm{L}$ of mixed standard solution and a curve already established in the microcomputer software (ChromQuest 4.2.34, version 3.1.6).

To study the histological structure of the small intestinal mucosa, samples were collected from $1.5 \mathrm{~cm}$ sized portions of the duodenum and jejunum, which were opened by the mesenteric border, fixed on filter paper and stored in histological cassettes and placed in glass vials containing $100 \mathrm{ml}$ of aqueous solution of $10 \%$ formalin for 24 hours. After this period, the samples were dehydrated in increasing alcohol series, 70 to $100 \%$, cleared in xylene and immersed in paraffin. The samples were submitted to cut of $5 \mu \mathrm{m}$ thickness, in microtomo, being made 8 semiserial sections. Two samples of each segment were stained with haematoxylin-eosin to perform the measures in the intestinal mucosa. For the analysis of histological slides a light microscope (Olympus BX41) was used, coupled to a system for capturing images (Olympus DP11-N) and an image analyser program (Image $J \AA$ ), with 125 -fold magnification. Histological analysis was evaluated on villus height $(\mathrm{VH})$ and crypt depth (CD), with 20 readings per slide being carried out for each parameter in villi and crypts. From the VH and CD data, the VH/CD ratio was calculated.

After all the samples had been collected, the organs of the digestive tract were removed, separated and weighed, with the stomach, small intestine, large intestine, caecum and colon being emptied before weighing.

\section{Statistical analyses}

The statistical analysis was performed using the software Statistical Analysis System (SAS Institute, 2002). The percentages of diarrhoea occurrence were calculated and the data submitted to radical transformation (to fit the premises of the analysis of variance. The data were submitted to analysis of variance to 0.05 of significance and regression, where the degrees of freedom, related to the levels of NDF in diets, were unfolded in polynomials, to establish the curve that best describes the behaviour of the data.

\section{RESULTS AND DISCUSSION}

During the experimental period the average temperature was $28.10^{\circ} \mathrm{C}$, with $33.12^{\circ} \mathrm{C}$ and $23.58^{\circ} \mathrm{C}$ being the maximum and minimum temperatures, respectively. The relative humidity was $62.36 \%$. The average temperature 
observed was above the ideal range of thermal comfort for weaned piglets $\left(22-24{ }^{\circ} \mathrm{C}\right) \mathrm{kept}$ in conditions of relative humidity of $50-70 \%$, but below the upper critical temperature $\left(35^{\circ} \mathrm{C}\right)$, thereby ensuring a suitable thermal environment for expressing the productive potential of the animals, in accordance with Hannas (1999).

\section{Performance and diarrhoea occurrence}

A quadratic effect on weight gain and feed conversion was observed in the period from 21 to 32 days of age with decreasing linear effect in the occurrence of diarrhoea, according to increased dietary NDF level (Table 2). The best NDF level estimated for both performance variables was $10.4 \%$, while for the occurrence of diarrhoea it was $16.5 \%$.

The performance results show that NDF levels in the diet that were lower or higher than estimated negatively affected animal performance, reflecting the effect of NDF levels on the nutrient digestibility of the diet once the amount of nutrients and energy available for basal metabolism and production of the piglets is directly related to weight gain rate.

The estimated level of NDF in the diet that resulted in the best performance of piglets differed in part from those reported by some researchers. Schiavon et al. (2004) observed a reduction in the weight gain of piglets fed with a diet in which the inclusion of beet pulp resulted in a diet with $18.5 \%$ NDF. However, Högberg and Lindberg (2004) observed that an increase from 10.5 to $21.5 \% \mathrm{NDF}$ in the diet resulted in a greater weight gain for weaned piglets. In turn, Mateos et al. (2006) also observed that piglets' performance was not affected when they were fed with diets containing 6\% NDF. For the different results regarding the effects of dietary fibre (DF) on pig performance, the association of physiological effects caused by the physical and chemical characteristics of fibre components with the degree of lignification and the amount of feed included used as a source of fibre should be considered (Wenk, 2001).

The reduction of the inclusion of soybean meal and extruded soybean associated with the increased inclusion of wheat bran in diets, in accordance with increases in the NDF level, may explain the reduced frequency of diarrhoea, given the high soluble fibre content in these feedstuffs, which may serve as a substrate for the pathogenic bacteria. In contrast, the by-product of wheat, characterized as a source of insoluble non-starch polysaccharides, constituted mainly by insoluble cellulose and arabinoxylans, stimulates intestinal mechanical motility, accelerating the intestinal transit (Cummings; Stephen, 1980; Selvendran, 1984; Wilfart et al., 2007).

Mateos et al. (2006) and Kim et al. (2008) reported that adding insoluble fibre leads to a reduction in diarrhoea in weaned piglets. According to Schley and Field (2002) and Yin et al. (2004), the inclusion of insoluble fibre may limit the adherence of pathogenic bacteria, immobilizing or reducing its ability to remain in the gastrointestinal tract, resulting in its elimination in the faeces and a reduction of diarrhoea.

Table 2: Average daily feed intake (ADFI), average daily gain (ADG), feed conversion ratio (FCR) and average occurrence of diarrhoea transformed (AODT) of pigs from 21 to 42 days fed with diets with different levels of neutral detergent fibre.

\begin{tabular}{|c|c|c|c|c|c|c|c|c|}
\hline \multirow{2}{*}{ Variables } & \multicolumn{5}{|c|}{ Neutral detergent fibre (\%) } & \multirow{2}{*}{ CV (\%) } & \multirow{2}{*}{$\begin{array}{l}\text { Effect } \\
\text { regression }\end{array}$} & \multirow{2}{*}{$P$ value } \\
\hline & 8.5 & 10.5 & 12.5 & 14.5 & 16.5 & & & \\
\hline \multicolumn{9}{|c|}{21 to 32 days of age } \\
\hline ADFI (kg) & 0.174 & 0.184 & 0.190 & 0.168 & 0.166 & 10.13 & NS & 0.0724 \\
\hline ADG (kg) & 0.125 & 0.134 & 0.135 & 0.099 & 0.092 & 24.20 & Quadratic1 & 0.0132 \\
\hline FCR $(\mathrm{kg} / \mathrm{kg})$ & 1.470 & 1.443 & 1.427 & 1.765 & 2.032 & 24.12 & Quadratic2 & 0.0113 \\
\hline \multicolumn{9}{|c|}{21 to 42 days of age } \\
\hline ADFI (kg) & 0.309 & 0.311 & 0.319 & 0.299 & 0.286 & 12.50 & NS & 0.5356 \\
\hline ADG (kg) & 0.208 & 0.210 & 0.217 & 0.197 & 0.198 & 14.68 & NS & 0.3832 \\
\hline $\mathrm{FCR}(\mathrm{kg} / \mathrm{kg})$ & 1.487 & 1.481 & 1.485 & 1.534 & 1.570 & 6.49 & NS & 0.0929 \\
\hline AODT & 2.508 & 2.312 & 2.116 & 1.921 & 1.725 & 32.09 & Linear $^{3}$ & 0.046 \\
\hline
\end{tabular}

CV - Coefficient of variation; NS - not significant; ${ }^{1} y=-0.0013 x^{2}+0.0271 x-0.0095$ and $R^{2} 0.84 ;{ }^{2} y=0.0171 x^{2}-0.3552 x+3.2543$ and $R^{2} 0.96 ;{ }^{3} y=-0.0979 x+3.3402$ and $R^{2} 0.93$. 
The results of this study agree with those found by Hanczakoswska, Swiatkiewicz and Bialecka (2008), who tested supplementation levels of pure cellulose in the diets of weaned piglets and verified that the addition of this source of fibre resulted in lower occurrence of diarrhoea. On the other hand, the results disagree with results found by Carneiro et al. (2008) and Pascoal et al. (2012), who tested different fibre sources in piglets' diets and affirmed that the use of soluble fibre in piglets' diets caused a greater occurrence of diarrhoea.

\section{$\mathrm{pH}$ and viscosity of the digestive contents}

No effect of NDF level was observed on the $\mathrm{pH}$ and viscosity of the digesta of the different sections of the gastrointestinal tract of piglets (Table 3). In general, changes in the $\mathrm{pH}$ and viscosity of the bolus due to increased DF are related to specific action and a predominant source of soluble or insoluble fibre. Thus, in the present study, the absence of effects may be related to the reduced soluble fibre fraction of the four main feedstuffs and their fibre composition used in the formulation of diets.

However, it was observed that the $\mathrm{pH}$ of the stomach content was above the optimum range for pepsin activity (2 to 3 ), as proposed by Rajagopalan, Moore and Stein (1966), who reported that adequate production of hydrochloric acid by the parietal cells of the pig stomach is achieved only between the seventh and tenth week of life of piglets. In relation to the $\mathrm{pH}$ of the small intestine, $\mathrm{pH}$ values below the optimum range ( 7.8 to 8.1 ) were observed for the action of trypsin and chymotrypsin in accordance with Makkink et al. (1994). Thus, independently of the level of fibre in the diet, the physiological immaturity of the digestive system of piglets up to 42 days may result in less utilization of protein.

The results differ from those obtained by Freire et al. (2000), who found an increase in the $\mathrm{pH}$ of the caecum of piglets in the nursery phase fed diets with more than $15 \%$ NDF. Similarly, Ma et al. (2002) observed higher $\mathrm{pH}$ in the jejunum content of piglets fed with diets containing $10.6 \% \mathrm{NDF}$ from the inclusion of wheat bran. In turn, Högberg and Lindberg (2004) observed that an increase from 10.5 to $21.5 \%$ NDF resulted in a reduction in the $\mathrm{pH}$ of caecum and colon contents of weaned piglets.

In similar studies, Johansen et al. (1996) reported an increase in the viscosity of the stomach contents of pigs with an increasing level of non-starch polysaccharides in diets from 3.2 to $15.4 \%$ from by-products of oats inclusion.

Differences in the results among researches are possibly related to the types and levels of fibre sources, bearing in mind that a reduction in $\mathrm{pH}$ and an increase in the viscosity of the digestive contents were found in most cases in diets with the inclusion of high levels of soluble fibre sources.

\section{Gastrointestinal transit time}

A quadratic effect was verified on acid insoluble ash (AIA) excretion at 15, 18, 21 and 27 hours after supplying diet (Table 4, Figure 1). Initially, the increase in NDF level in the diet resulted in a reduction of AIA in faeces excreted at 15, 18, 21 and 27 hours after the feedhad been supplied, resulting in the lowest values for the levels of $10.2,11.0,11.1$ and $13.5 \%$ NDF, respectively. In turn, the inclusion of NDF above these levels resulted in higher excretion of AIA.

Table 3: $\mathrm{pH}$ and viscosity of the gastrointestinal tract contents of pigs from 21 to 42 days of age fed with diets with different levels of neutral detergent fibre.

\begin{tabular}{|c|c|c|c|c|c|c|c|c|}
\hline \multirow{2}{*}{ Parameters } & \multicolumn{5}{|c|}{ Neutral detergent fibre (\%) } & \multirow{2}{*}{$\begin{array}{l}\text { CV } \\
(\%)\end{array}$} & \multirow{2}{*}{$\begin{array}{c}\text { Effect } \\
\text { regression }\end{array}$} & \multirow{2}{*}{$P$ value } \\
\hline & 8.5 & 10.5 & 12.5 & 14.5 & 16.5 & & & \\
\hline \multicolumn{9}{|c|}{$\mathrm{pH}$} \\
\hline Stomach & 3.637 & 3.892 & 4.090 & 3.167 & 3.117 & 27.19 & NS & 0.3110 \\
\hline Small intestine & 5.702 & 5.670 & 5.675 & 5.707 & 5.900 & 4.64 & NS & 0.1940 \\
\hline Caecum & 5.517 & 5.533 & 5.447 & 5.762 & 5.615 & 4.32 & NS & 0.3970 \\
\hline \multicolumn{9}{|c|}{ Viscosity (mPa.s) } \\
\hline Stomach & 1.857 & 1.861 & 1.896 & 1.859 & 1.842 & 5.89 & NS & 0.8290 \\
\hline Small intestine & 2.013 & 2.094 & 2.120 & 2.005 & 2.079 & 5.95 & NS & 0.8460 \\
\hline Caecum & 1.896 & 1.986 & 2.009 & 2.021 & 2.193 & 8.00 & NS & 0.9330 \\
\hline
\end{tabular}

$\mathrm{CV}$ - Coefficient of variation; NS - not significant. 
Table 4: Concentration of acid insoluble ash in the faeces of piglets fed with diets with different levels of neutral detergent fibre according to the retention time of food.

\begin{tabular}{|c|c|c|c|c|c|c|}
\hline \multirow[b]{2}{*}{ Retention time } & \multicolumn{5}{|c|}{ Neutral detergent fibre (\%) } & \multirow{3}{*}{ Effect regression } \\
\hline & 8.5 & 10.5 & 12.5 & 14.5 & 16.5 & \\
\hline \multicolumn{6}{|c|}{ Acid insoluble ash (\%) } & \\
\hline 15 hours & 0.109 & 0.072 & 0.135 & 0.195 & 0.322 & Quadratic \\
\hline 18 hours & 0.116 & 0.103 & 0.128 & 0.098 & 0.244 & Quadratic \\
\hline 21 hours & 0.094 & 0.034 & 0.104 & 0.093 & 0.191 & Quadratic \\
\hline 24 hours & 0.104 & 0.152 & 0.096 & 0.082 & 0.078 & NS \\
\hline 27 hours & 0.088 & 0.026 & 0.012 & 0.064 & 0.029 & Quadratic \\
\hline
\end{tabular}

NS - not significant.

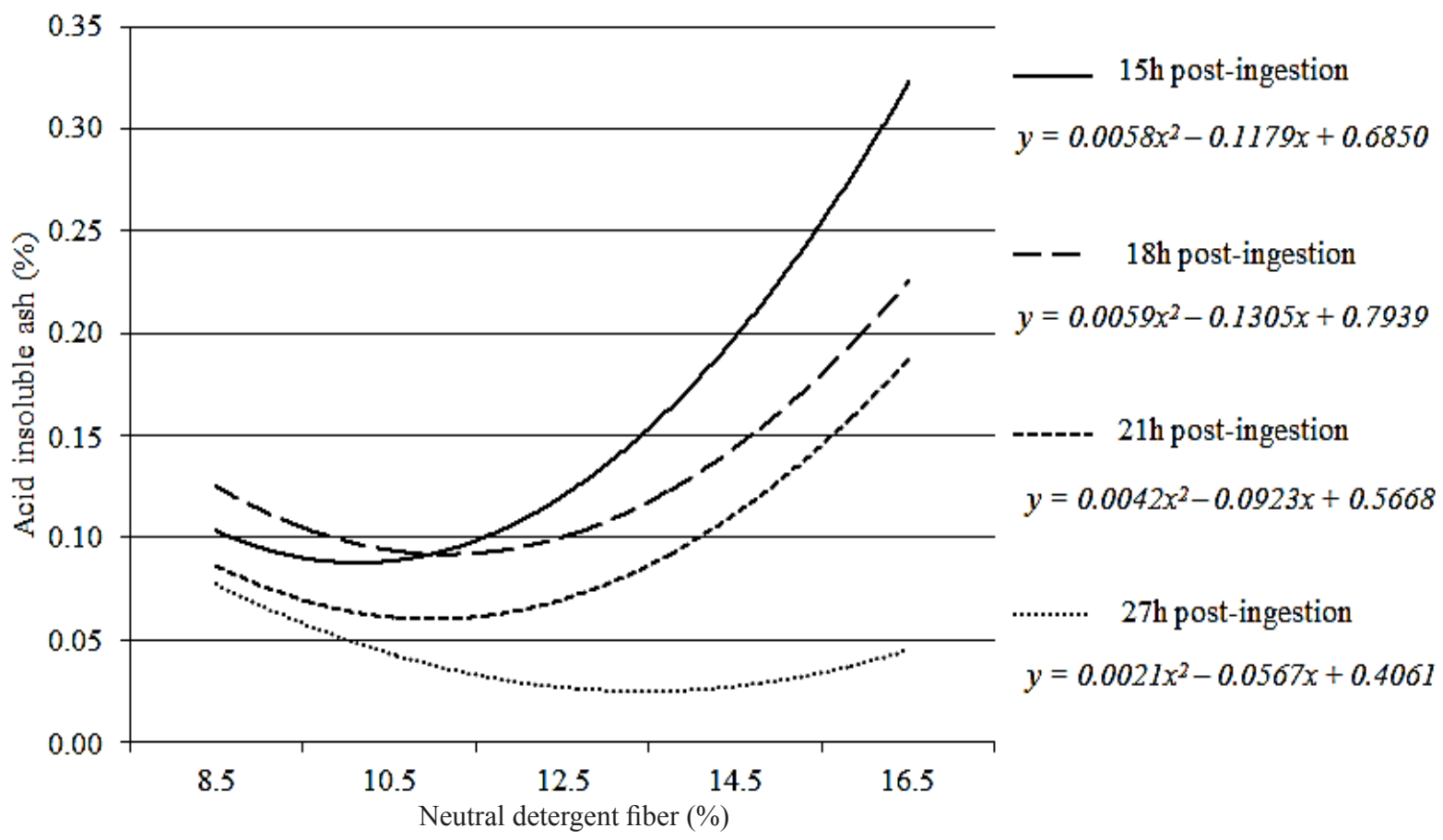

Figure 1: Excretion curves of acid insoluble ash-fed of piglets fed with diets with different levels of neutral detergent fibre (NDF).

Bearing in mind that a lower excretion of AIA reflects a greater retention time of feed in the gastrointestinal tract, NDF in the diet below or above the range of 10.2 to $13.5 \%$ resulted in a reduction of digesta transit time, indicating that the fibre exerts a regulatory role in the motility of digesta in the gastrointestinal tract.

This effect may be related to the low viscosity of the digesta, due to greater inclusion of wheat bran, insoluble fibre source, that exert mechanical action in the gastrointestinal tract, stimulating peristalsis and accelerating the transit of digesta (Cukier et al., 2005).

Similar results were found by Freire et al. (2000), who verified the reduction in transit time of the digesta of weaned piglets fed with diets containing $15.6 \% \mathrm{NDF}$, coming from the alfalfa meal. In the same way, Wilfart et al. (2007) observed that an increase from 22 to $27 \%$ of total DF reduced the digesta retention time in the digestive tract. 


\section{Concentration of short chain fatty acids}

According to Englyst, Shay and Macfarlane (1987), the proportion of short chain fatty acids (SCFA) in the caecum varies according to the fibre characteristics, microbial activity and the permanence time in the digestive tract; however, in this study the effect of NDF level on the concentration of acetic, propionic, butyric and total fatty acids in the caecum content of piglets was not verified (Table 5).

Schiavon et al. (2004) explain that for modulation of the caecal fatty acid profile a significant amount of substrate is necessary to bring about changes in the intestinal microflora, as it is a highly fermentable soluble fibre in this intestinal segment (Bach Knudsen, 2001), while the insoluble fibre is slowly fermented by the microflora in the distal large intestine (Freire et al., 2000). Thus, the absence of a significant effect on the fatty acid concentrations in this study may be associated with the variability of fibre sources and the greater inclusion of wheat bran to increase the levels of NDF in diets, which besides providing substrate for slow fermentation, tends to accelerate the intestinal transit (Wilfart et al., 2007), which is not conducive to microbial action in the large intestine.

\section{Histological parameters of the intestinal mucosa and morphology of the digestive organs}

It was observed that the increasing levels of NDF in diets resulted in modification of the intestinal mucosa structure (Table 6), showing a quadratic effect on the villus height in the duodenum and on the villus height and crypt depth in the jejunum, with the greatest villus height in both segments being estimated at $12.2 \%$ of NDF, this being responsible for the largest surface area available for digestion and absorption of nutrients, while levels below and above resulted in the increased wear of the mucosa structure, represented mainly by atrophy of the villus.
These results can be explained by the differences in the feedstuffs used to compose the experimental diets, where the diet with a lower content of NDF presented a higher amount of soybean by-products and soluble fibre source, while increasing the level of NDF in diets was accompanied by the gradual reduction of soybean byproducts and an increase in wheat bran and insoluble fibre source, mainly cellulose and arabinoxylans (Cummings and Stephen, 1980; Selvendran, 1984; Wilfart et al., 2007). Thus, diets with 8.5 and $10.5 \%$ NDF may have resulted in substrate for pathogenic bacteria in the intestinal tract, causing a possible inflammatory effect of the mucosa (Karr-Lilienthal et al., 2005; Brasil et al., 2009), while the diets with more than $12.2 \%$ NDF may have had a mechanical effect, limiting the adhesion of pathogenic bacteria that, possibly, were excreted in faeces, but the abrasive effect on the gut epithelium may have caused villus atrophy with increased shedding of cells, which can even increase the excretion of nitrogen in the faeces (Schley and Field, 2002; Yin et al., 2004).

The results agree with those reported by Hedemann et al. (2006), who observed an increase in the loss of cell rate in the villus with the increase of soluble fibre sources, while the greatest insoluble fibre level resulted in improvement in the intestinal morphology of weanling piglets. Moreover, McDonald et al. (2001), evaluating the effect of a soluble synthetic fibre and little viscous (carboxymethyl) in diets for weanling piglets, found an increase in villus height. In turn, Hanczakowska, Swiatkiewicz and Bialecka (2008) found that diets containing $22.5 \%$ NDF with the addition of up to $2 \%$ cellulose improved the ratio of villus height and crypt depth in the mucosa of the small intestine of piglets.

Changes were observed in the weight of gastrointestinal tract segments, with a linear increase being detected in the weights of the stomach, caecum and colon in line with an increase in the NDF level in diets (Table 7).

Table 5: Concentration of short chain fatty acids (SCFAs) in the caecum of piglets from 21 to 42 days fed with diets with different levels of neutral detergent fibre.

\begin{tabular}{|c|c|c|c|c|c|c|c|c|}
\hline \multirow{2}{*}{$\begin{array}{c}\text { SCFA } \\
(\mathrm{mmol} / \mathrm{L})\end{array}$} & \multicolumn{5}{|c|}{ Neutral detergent fibre (\%) } & \multirow{2}{*}{ CV (\%) } & \multirow{2}{*}{$\begin{array}{c}\text { Effect } \\
\text { regression }\end{array}$} & \multirow{2}{*}{$P$ value } \\
\hline & 8.5 & 10.5 & 12.5 & 14.5 & 16.5 & & & \\
\hline Acetate & 28.37 & 32.91 & 26.70 & 27.44 & 27.26 & 17.29 & NS & 0.449 \\
\hline Propionate & 16.07 & 18.39 & 17.06 & 18.00 & 15.91 & 20.99 & NS & 0.494 \\
\hline Butyrate & 8.10 & 8.99 & 10.32 & 9.41 & 10.36 & 24.71 & NS & 0.541 \\
\hline Total SCFA & 52.54 & 60.28 & 54.08 & 54.84 & 53.53 & 17.71 & NS & 0.617 \\
\hline
\end{tabular}

CV - Coefficient of variation; NS - not significant. 
Table 6: Histological parameters of the intestine of piglets from 21 to 42 days fed with diets with different levels of neutral detergent fibre.

\begin{tabular}{|c|c|c|c|c|c|c|c|c|}
\hline \multirow{2}{*}{ Parameters } & \multicolumn{5}{|c|}{ Neutral detergent fibre (\%) } & \multirow{2}{*}{ CV (\%) } & \multirow{2}{*}{ Effect regression } & \multirow{2}{*}{$P$ value } \\
\hline & 8.5 & 10.5 & 12.5 & 14.5 & 16.5 & & & \\
\hline \multicolumn{9}{|c|}{ Duodenum } \\
\hline $\mathrm{VH}(\mu \mathrm{m})$ & 0.290 & 0.290 & 0.327 & 0.288 & 0.282 & 20.53 & Quadratic1 & 0.0001 \\
\hline $\mathrm{CP}(\mu \mathrm{m})$ & 0.194 & 0.191 & 0.191 & 0.191 & 0.187 & 24.91 & NS & 0.3198 \\
\hline $\mathrm{VH} / \mathrm{CP}$ & 1.504 & 1.499 & 1.711 & 1.506 & 1.608 & 19.14 & NS & 0.6180 \\
\hline \multicolumn{9}{|c|}{ Jejunum } \\
\hline $\mathrm{VH}(\mu \mathrm{m})$ & 0.258 & 0.287 & 0.295 & 0.272 & 0.243 & 16.75 & Quadratic2 & 0.0001 \\
\hline $\mathrm{CP}(\mu \mathrm{m})$ & 0.187 & 0.198 & 0.190 & 0.184 & 0.171 & 24.41 & Quadratic3 & 0.0001 \\
\hline $\mathrm{VH} / \mathrm{CP}$ & 1.427 & 1.479 & 1.580 & 1.477 & 1.421 & 19.99 & NS & 0.6864 \\
\hline
\end{tabular}

CV - Coefficient of variation; NS - not significant; VH - villus height; CP - crypt depth; VH/CP - villus height/crypt depth relationship; ${ }^{1} y=-0.0016 x^{2}+0.0385 x+0.0728$ and $R^{2} 0.46 ;{ }^{2} y=-0.0025 x^{2}+0.0604 x-0.0766$ andR $R^{2} 0.98 ;{ }^{3} y=-0.0008 x^{2}+$ $0.0183 x+0.0929$ and $R^{2} 0.93$.

Table 7: Average weight of the digestive organs (expressed in percentage of live weight) of piglets from 21 to 42 days of age fed with diets with different levels of neutral detergent fibre.

\begin{tabular}{|c|c|c|c|c|c|c|c|c|}
\hline \multirow{2}{*}{ Digestive organs } & \multicolumn{5}{|c|}{ Neutral detergent fibre (\%) } & \multirow{2}{*}{ CV (\%) } & \multirow{2}{*}{$\begin{array}{l}\text { Effect } \\
\text { regression }\end{array}$} & \multirow{2}{*}{$P$ value } \\
\hline & 8.5 & 10.5 & 12.5 & 14.5 & 16.5 & & & \\
\hline \multicolumn{9}{|c|}{ Average weight of the digestive organs (kg) } \\
\hline Liver & 3.35 & 3.42 & 3.08 & 2.65 & 3.10 & 19.83 & NS & 0.2952 \\
\hline Pancreas & 0.25 & 0.26 & 0.27 & 0.26 & 0.25 & 22.99 & NS & 0.8492 \\
\hline Stomach & 0.75 & 0.82 & 0.86 & 0.97 & 0.93 & 8.85 & Linear1 & 0.0001 \\
\hline Small intestine & 5.00 & 5.06 & 4.60 & 4.79 & 4.60 & 10.12 & NS & 0.1847 \\
\hline Caecum and colon & 1.64 & 1.61 & 1.70 & 1.79 & 1.94 & 16.23 & Linear2 & 0.0283 \\
\hline Rectum & 0.447 & 0.463 & 0.421 & 0.455 & 0.397 & 21.37 & NS & 0.6115 \\
\hline
\end{tabular}

CV - Coefficient of variation; NS - not significant; ${ }^{1} y=0.0091 x+0.7225$ and $R^{2} 0.86 ;{ }^{2} y=0.0144 x+1.5135$ and $R^{2} 0.84$.

Previous studies have demonstrated an increase in the weight of visceral organs in response to the inclusion of fibre in pigs' diets. Pekas, Yen and Pond (1983) found a higher weight of the colon of finishing pigs fed with $50 \%$ alfalfa hay. Jorgensen et al. (1996) found that animals fed with diets containing $26.8 \%$ of DF had a larger stomach, caecum and colon. On the other hand, Kass, Van Soest and Pond (1990) observed both lower weight and greater weight of the stomach, small intestine, caecum and colon of pigs fed diets containing 43\% NDF, whereas Jin et al. (1994) found no effect on the weight of visceral organs by comparing diets with 11.6 and $16.5 \%$ NDF.

\section{CONCLUSIONS}

It is concluded that, in diets for weaned piglets, the increase in NDF level from $8.5 \%$ to $16.5 \%$ does not change the $\mathrm{pH}$ and viscosity of the digesta and the caecal production of short chain fatty acids, but regulates the transit time of digesta, with levels below $10.2 \%$ and above $13.5 \%$ reducing the transit time of digesta. The estimated level of $12.2 \%$ of NDF is responsible for the best histological structure of the small intestinal mucosa, with an increase in the weights of the stomach, caecum and colon and a reduction in the occurrence of diarrhoea with increasing NDF level in diets, resulting in a better performance of weaned piglets with $10.4 \%$ of NDF. 


\section{ACKNOWLEDGEMENTS}

The authors acknowledge the Banco do Nordeste do Brasil (BNB) for its financial support of the research project and the Universidade Federal do Ceará (UFC) for providing the infrastructure necessary for conducting the research.

\section{REFERENCES}

ANNISON, G.; CHOCT, M. Plant polysaccharides - their physicochemical properties and nutritional roles in monogastric animals. In: LYONS, T. P.; JACQUES, K. A. Biotechnology in the feed industry. Proceedings of the 10th Alltech Annual Symposium; 1994; England: Nottingham University Press, p.51-66. 1994.

ASSOCIATION OF OFFICIAL ANALYTICAL CHEMISTSAOAC. Official methods of analysis. 15. ed. Arlington: 1990, 1078p.

BACH KNUDSEN, K. E. The nutritional significance of "dietary fibre" analysis. Animal Feed Science and Technology, 90(1-2):3-20, 2001.

BRASIL, A. P. R. et al. Removal of oligosaccharides in soybean flour and nutritional effects in rats. Food Chemistry, 118(2):251-255, 2009.

CARNEIRO, M. S. C. et al. Effects of dietary fibre source and enzyme supplementation on faecal apparent digestibility, short chain fatty acid production and activity of bacterial enzymes in the gut of piglets. Animal Feed Science and Technology, 146(1-2):124-136, 2008.

CUKIER, C.; MAGNONI, D.; ALVAREZ, T. Nutrição baseada na fisiologia dos órgãos e sistemas. São Paulo: Sarvier, 2005. 332p.

CUMMINGS, J. H.; STEPHEN, A. M. The role of dietary fiber in the human-colon. Canadian Medical Association Journal, 123(11):1109-1114, 1980.

ENGLYST, H. N.; SHAY, G. T.; MACFARLANE, S. Polysaccharide breakdown by mixed populations of human faecal bacteria. FEMS Microbiology Ecology, 95(3):163-171, 1987.

ERWIN, W. S.; MARCO, G. J.; MERY, E. M. Volatile fat acid analyses of blood and rumen fluid by gas chromatography. Journal of Dairy Science, 44(9):1768-1771, 1961.

FREIRE, J. P. B. et al. Effect of dietary fibre source on total tract digestibility, caecum volatile fatty acids and digestive transit time in the weaned piglet. Animal Feed Science and Technology, 87(1-2):71-83, 2000.
HANCZAKOWSKA, E.; SWIATKIEWICZ, M.; BIALECKA, A. Pure cellulose as feed supplement for piglets. Medycyna Weterynaryjna, 64(1):45-48, 2008.

HANNAS, M. I. Aspectos fisiológicos e a produção de suínos em clima quente. In: SILVA, I. J. O. Ambiência e qualidade na produção industrial de suínos. Piracicaba: Fundação de Estudos Agrários Luiz de Queiroz; 1999. p.1-33.

HEDEMANN, M. S. et al. Intestinal morphology and enzymatic activity in newly weaned pigs fed contrasting fiber concentrations and fiber properties. Journal of Animal Science, 84(6):1375-1386, 2006.

HÖGBERG, A.; LINDBERG, J. E. Influence of cereal non-starch polysaccharides and enzyme supplementation on digestion site and gut environment in weaned piglets. Animal Feed Science and Technology, 116(1-2):113-128, 2004.

JIN, L. et al. Effects of dietary fiber on intestinal growth cell proliferation and morphology in growing pigs. Journal of Animal Science, 72(9):2270-2278, 1994.

JOHANSEN, H. N. et al. Effects of varying content of soluble dietary fibre from wheat flour and oat milling fractions on gastric emptying in pigs. British Journal of Nutrition, 75(3):339-351, 1996.

JØRGENSEN, H. et al. The influence of dietary fibre source and level on the development of the gastrointestinal tract, digestibility and energy metabolism in broiler chickens. British Journal of Nutrition, 75(3):379-395, 1996.

KARR-LILIENTHAL, L. K. et al. Chemical and nutritional properties of soybean carbohydrates as related to no ruminants: a review. Livestock Production Science, 97(1):1-12, 2005.

KASS, M. L.; VAN SOEST, P. J.; POND, W. G. Utilization of dietary fiber from alfalfa by growing swine. II. Volatile fatty acid concentrations in and disappearance from the gastrointestinal tract. Journal of Animal Science, 50(1):192-197, 1980.

KIM, J. C. et al. Addition of oat hulls to an extruded ricebased diet for weaner pigs ameliorates the incidence of diarrhoea and reduces indices of protein fermentation in the gastrointestinal tract. British Journal of Nutrition, 99(6):1217-1225, 2008.

$M A$, Y. et al. The effects of fiber source on organ weight, digesta $\mathrm{pH}$, specific activities of digestive enzymes and bacterial activity in the gastrointestinal tract of piglets. AsianAustralasian Journal of Animal Sciences, 15(10):14321488, 2002. 
MCDONALD, D. E. et al. Increasing viscosity of the intestinal contents alters small intestinal structure and intestinal growth and stimulates proliferation of enterotoxigenic Escherichia coli in newly-weaned pigs. British Journal of Nutrition, 86(4):487-498, 2001.

MAKKINK, C. A. et al. Gastric protein breakdown and pancreatic enzyme activities in response to different dietary protein sources in newly weaned pigs. Journal of Animal Science, 72(11): 2843-2850, 1994.

MATEOS, G. G. et al. The effect of inclusion of oat hulls in pig diets based on raw or cooked rice and maize. Journal of Animal Science, 82(1-2):57-63, 2006.

MONTAGNE, L.; PLUSKE, J. R.; HAMPSON D. J. A review of interactions between dietary fibre and the intestinal mucosa and their consequences on digestive health in young non-ruminant animals. Animal Feed Science and Technology, 108(1-4):95-117, 2003.

NATIONAL RESEARCH COUNCIL-NRC. Nutrient requirements of swine. 11. ed. Washington: National Academic, 2012. Press.

PASCOAL, L. A. F. et al. Fiber sources in diets for newly weaned piglets. Revista Brasileira de Zootecnia, 41(3):636-642, 2012.

PEKAS, J. C.; YEN, J. T.; POND, W. G. Gastrointestinal carcass and performance traits of obese versus lean genotype swine: effect of dietary fiber. Nutrition Reports International, 27(2):259-270, 1983.

RAJAgOPAlAN, T. G.; MOORE, S.; STEIN, W. H. Pepsin from pepsinogen, preparation and properties. Journal of Biological Chemistry, 241(21):4940-4950, 1966.

REFSTIE, S. et al. Nutrient digestibility in Atlantic salmon and broiler chickens related to viscosity and nonstarch polysaccharides content in different soybean products. Animal Feed Science and Technology, 79(4):331-345, 1999.

ROSTAGNO, H. S. et al. Tabelas Brasileiras para aves e suínos: composição de alimentos e exigências nutricionais. Viçosa, MG: Universidade Federal de Viçosa, 2011. 252p.
SAS Institute. SAS User's guide: Statistics. Version 8. Cary: NC, 2002.

SCHIAVON, S. et al. Effects of sugar beet pulp on growth and health status of weaned piglets. Italian Journal of Animal Science, 3(4):337-351, 2004.

SCHLEY, P. D.; FIELD, C. J. The immune-enhancing effects of dietary fibres and prebiotics. British Journal of Nutrition, 87(2):221-230, 2002.

SELVEDRAN, R. R. The plant cell wall as a source of dietary fiber: chemistry and structure. The American Journal of Clinical Nutrition, 39(2):320-337, 1984.

VAN KEULEN, J.; YOUNG, B. A. Evaluation of acid insoluble ash as a natural markers in ruminant digestibility studies. Journal of Animal Science, 44(2):282-287,1997.

VAN SOEST, P. J.; ROBERTSON, J. B.; LEWIS, B. A. Methods for dietary fiber. Neutral detergent fiber and non-starch polysaccharides in relation to animal nutrition. Journal of Dairy Science, 74(10):3583-3597, 1991.

VAN SOEST, P. J.; WINE, R. H. Use of detergents in the analysis of fibrous feeds. IV - Determination of plant cell-wall constituents. Journal of the Association of Official Analytical Chemists, 50(1):50-55, 1967.

WENK, C. The role of dietary fibre in the digestive physiology of the pig. Animal Feed Science and Technology, 90(12):21-33, 2001.

WILFART, A. et al. Effect of fibre content in the diet on the mean retention time in different segments of the digestive tract in growing pigs. Livestock Science, 109(13):27-29, 2007.

YIN, Y. L. et al. Nutritional and health functions of carbohydrate for pigs. Animal Feed Science and Technology, 13(4):523538, 2004.

ZHANG, L. et al. The effect of soybean galactooligosaccharides on nutrient and energy digestibility and digesta transit time in weanling piglets. Asian-Australasian Journal of Animal Sciences, 14(11):1598-1604, 2001. 